\title{
Groundwater and Hydraulic Opulence in the Late Nineteenth Century
}

\author{
"Well, in our country," said Alice, still panting a little, "you'd generally get to \\ somewhere else-if you ran very fast for a long time, as we've been doing." \\ "A slow sort of country!" said the Queen. "Now, here, you see, it takes all the \\ running you can do, to keep in the same place. If you want to get somewhere \\ else, you must run at least twice as fast as that!" \\ -LEWIS CARROLL, THROUGH THE LOOKING GLASS
}

In the second half of the nineteenth century artesian wells tapped into groundwater, ending centuries of water scarcity and greatly expanding access to baths in Mexico City. The individualized immersion bath (placer) once offered to wealthier, more European clients was now available to almost everybody. Many of the downtown bathhouses that served humble city dwellers shuttered their temazcales and replaced them with low-cost wooden placeres grouped together in a shared room. ${ }^{1}$ These humble bathhouses charged for each bucket of hot water, but usually provided all the cold water a client wished, and they used much more water for their wooden placeres than they had for the temazcales that preceded them. At the same time as the placer was being adopted by the masses in the old bathhouses of the city center, new and exclusive bathing facilities were sprouting up on the western side of the city along the Paseo de la Reforma that offered both social and individual contacts with great volumes of water in a variety of forms including swimming pools, tubs, steam rooms, and showers. ${ }^{2}$ Bathers in both new and old bathhouses luxuriated in an unprecedented hydraulic opulence provided by seemingly unlimited groundwater from artesian wells.

The abundance of groundwater reshaped the practices and social relations of bathing in Mexico. In this chapter I discuss how, around 1850, bountiful, clean water was supplied in places that had not been served previously by existing infrastructure, and in quantities that enabled bathing with more frequency, with more water. Existing bathhouses turned into immersion baths, and many new lavish, modern bathing centers, or balnearios, were built that offered a much wider range 
of contacts with waters, including swimming, diving, wet and dry saunas, drinking fountains, and splashing pools for children. Groundwater filled pools in urban and rural settings, expanding the practice of swimming for fun and fitness that was before mostly limited by access to natural bodies of surface water. The expansion of bathing in the late nineteenth century was backed by a new assumption that water was available in large amounts-a structured feeling of hydraulic opulence that emerged along with artesian wells. The political ecology of groundwater presented in this chapter shows how infrastructure, bathing practices, and concepts of cleanliness evolved together. ${ }^{3}$

Easy groundwater during late nineteenth- and twentieth-century Mexico made both social and individual bathing more common. Jeff Wiltse shows that in the United States after 1940, extensive water infrastructure enabled the proliferation of private backyard pools, resulting in Americans "bathing alone" rather than together in public pools. ${ }^{4}$ In the late nineteenth and early twentieth centuries in Mexico we see a similar growth of the water supply, but the individualization of bathing was a more ambivalent process. Despite the availability of water, and the connotations of luxury and modernity offered by private bathing, Mexicans continued to bathe together. Poor people soaked and scrubbed in individual placeres in large shared rooms, and wealthy Mexicans met to socialize and take the waters in elaborate bathhouses. While the hygienic and sanitary function of bathhouses slowly moved to household bathrooms in the twentieth century, social bathing for fun and fitness continued to flourish in the country's baths.

\section{THE GROUNDWATER REVOLUTION}

The scarcity of clean water that characterized the colonial period continued unabated after independence, as did government efforts to police the shortage through the identification of new sources and the construction of infrastructure. As was discussed in chapter 4, for centuries water from the aqueducts of Mexico City was concessioned to wealthy property owners or delivered to the public fountains. There were also shallow wells used by the city government for cleaning the streets, and the plebian mass often used these for their houses, their animals, themselves, and their clothes, as they did the water that flowed through the city's drainage canals and the rivers on the outskirts of the city. People liked to wash and bathe in the water of the wells and drainage canals because it was softer than the city water and produced more suds. More importantly, it was available and free. But the quality of those waters was dubious and the public bathing they supported was frowned upon by many.

In the 1830 s city officials sought to increase the supply of water, and set their sights on the Xacopinca spring, located to the north near the towns of Azcapotzalco and Tacuba. This was a spring that first served the pre-Hispanic settlements on the islands in the lake, conducting water through an aqueduct to the town of Tlatelolco, 
north of Tenochtitlán. In the 1400 s this water system was overshadowed by the aqueduct built to carry water from the Chapultepec springs to Tenochtitlán. After it was destroyed by the Spaniards, the Xacopinca aqueduct was only restored to working order for a brief time at the beginning of the seventeenth century, despite periodic renewed interest. The city owned the spring, and in 1839 once again studied the possibility of integrating Xacopinca into the city's infrastructure, calculating that the sale of the water could pay for the works. In 1843 the city signed a deal with a private investor who offered to finance and build an aqueduct from the Xacopinca spring to the fountain in the plaza of Tlatelolco in exchange for the right to sell the water. In order to stop the existing access and uses of the water by local peasants, the business was given permission to build walls around the water source.

The chemist Leopoldo Río de la Loza was commissioned to conduct an analysis of the mineral and biological contents of the Xacopinca waters. ${ }^{5} \mathrm{He}$ found it to be "better" (less dissolved solids) than the agua gorda (hard water-literally "thick water") of Chapultpec and "worse" than the agua delgada (soft water-literally "thin water") of Santa Fe, and concluded that channeling the spring would have the double benefit of providing potable water for the city and removing an unhealthy swamp at the site of the spring. ${ }^{6}$ The gradient for the kilometer-long aqueduct to deliver the water to Tlatelolco was adequate, but by the 1850 s the springflow had dwindled so much that there was not enough pressure to move the water down the aqueduct, and the quantity of water was insufficient to justify the expense. With this plan to increase supplies of water frustrated, in 1854 the city administrators instead reduced the amount of water delivered to each user by installing "economical faucets" throughout the system, a measure that raised the ire of the bathhouse proprietors. ${ }^{8}$

Despite the scarcity of water, the demand for baths continued to increase, and businessmen built new baths or expanded existing ones. Santiago Vega founded the Baños del Amor de Dios in 1853, and in 1866 asked for a fifty percent increase in the water concession. In 1856 José Guadalupe Velásquez asked for "one more concession" of water for his baños at Number 11 Calle Don Toribio, and the next year Manuel Murguía petitioned the city for a merced of five "pajas de agua" (about $10 \mathrm{cc} / \mathrm{second}$ ) for a new bathhouse he aimed to build in the Plazuela de Juan Carbonero. The bathhouse was built and the water delivered, but subsequent pleas for more water in 1861 and 1877 suggest that the number of people in the city who wished to bathe kept growing. ${ }^{9}$

After 1850, the perforation of artesian wells seemed to erase the limits to the supply of good quality water. Engineers armed with new drilling equipment and techniques opened hundreds of artesian wells in the Valley of Mexico during the last half of the nineteenth century, part of a global groundwater revolution. ${ }^{10}$ Artesian waters emerge under their own pressure, without pumping. Wells are drilled in a location where the surface of the ground, or wellhead, is lower than a portion of the aquifer that lies above the wellhead, and so the water flows downhill 
within the aquifer and then flows up and out of the well bore. This is common for aquifers located in sloping land, such as the Valley of Mexico. Artesian wells mimic naturally occurring springs, the difference being that a route is opened artificially by a drill for the water to reach the surface. The Valley of Mexico was a geological formation that was suited to artesian wells, as there were altitude differentials in the subsoil water that created hydrostatic pressure that was maintained by geological formations of alluvial silt and clay. In that context, water would spring unaided anywhere that a well opened access to that confined aquifer.

In Mexico, attempts had been made in the early part of the nineteenth century, but artesian wells only became common in the 1850 . ${ }^{11}$ This was largely due to the efforts of Sebastián Pane, who by 1854 had opened at least 20 artesian wells, and by 1857 had completed 144 wells, 24 for use in irrigation and the control of dust on public roads, and 120 for the houses of individuals. ${ }^{12}$ Pane used the "Chinese" system of drilling, a technique of percussion drilling with a heavy chisel on the end of a rope, which was pioneered a thousand years ago to tap water and natural gas with wells hundreds of feet deep in the province of Szechuan. ${ }^{13}$ Soon others were using a different system that enabled even deeper exploration, and by the 1860 s there was a lively discussion of drilling techniques and many companies were operating drilling rigs in Mexico. ${ }^{14}$ Pane, however, continued to lead the industry, completing hundreds of artesian wells in Mexico City, as well as in the cities of Veracruz, Tampico, Cordoba, Manzanillo, and Mazatlán. ${ }^{15}$ In the 1850 s he opened a business office on a plot of land on Paseo de la Reforma, where he contracted to build wells for individual houses or groups of houses, and a few years later he built the famous Alberca Pane bathhouse on that property. ${ }^{16} \mathrm{He}$ even received permission from the Ministry of Development to experiment with using wells to desiccate Lake Texcoco by draining its waters into the subsoil. ${ }^{17}$

The advent of the artesian wells brought easy water, and a hope of finally resolving centuries of water scarcity and the social struggles and policing engendered by it. Most of the wells sunk in the city by Pane in the 1850 os were for "private houses," but three of them - at Los Migueles, Bucareli, and Cordobanes-provided water to the public in the city center to supplement the Santa Fe aqueduct and the springs of Chapultepec. ${ }^{18}$ In 1863 Pane signed a contract with the city's Comisión de Aguas to open eight new artesian wells in different plazas in the historical center of Mexico City, and in 1869 the city ordered another three wells drilled for neighborhoods that did not have adequate water service. ${ }^{19}$ Some, such as the well in the plaza of Salto del Agua, served existing public fountains. In 1871 two more were sunk near San Lázaro and in 1872 twelve more public wells were drilled, with five of those to the west of the city center on the Paseo de la Reforma. ${ }^{20}$ Still, most wells were private, and served the wealthy. By 1883 Mexico City had 483 wells, thanks to a growing professional cadre of engineers with drilling equipment. ${ }^{21}$ About a third of these wells were located in the city's Octava Demarcación, which included the new, wealthy neighborhoods to the west of the city center along Paseo de la 
Reforma, from Bucareli to Chapultepec. ${ }^{22}$ The bathhouses and swimming pools that were all the rage in the era of President Porfirio Díaz (1877-1911, known as the "Porfiriato") were located in this area, and they were served by artesian wells. The flurry of drilling led by Pane almost doubled the entire water supply in the city by the 1860 s and almost tripled it by $1883 .{ }^{23}$ In 1895 public artesian wells provided about a quarter of the water that coursed through the city's distribution system. ${ }^{24}$

Hundreds of artesian wells were not capped, but rather left to flow freely and create wetlands that city leaders viewed as dangerous to public health. Near the Chapultepec springs, "three or more artesian wells without faucets" coursed, puddled, and eventually mixed with waters leaking from the aqueduct that supplied the fountain at Salto del Agua. ${ }^{25}$ But even without this wastage, the huge increase in water supply between 1853 and 1883 saturated the drainage system in the city, adding to fears of "infectious waters," miasmas, putrefaction, and other threats. In response to this new abundance of groundwater, the city government issued a series of dispositions regulating extraction but, more than anything, disposal of the liquid. ${ }^{26}$ In some cases the government required well operators to channel their excess waters to public fountains, but these regulations were generally not enforced.

There were signs from the beginning of the boom that groundwater was finite, but not everyone wished to recognize them. Wells began to dry up and dwindle just a few years after they were sunk. ${ }^{27}$ When Antonio Peñafiel visited the Xacopinca spring in the 188 os to assess the hygienic qualities of its waters, he noted that the water pressure had fallen so much that the spring was stagnant, although he failed to link this fact to the rise in the number of artesian wells he documented elsewhere. ${ }^{28}$ The profusion of new artesian wells also caused water pressure to drop significantly in the aquifer that gave rise to the Chapultepec springs, reducing the flow through the aqueduct to the fountain at Salto del Agua. But when asked by the city about the likelihood that these shortages were caused by the installation of an artesian well nearby in the Hormiga parcel (now next to the presidential residence in the Bosque de Chapultepec), engineer Francisco Herrera rejected the possibility, arguing that the springs were just clogged. ${ }^{29}$ Others in the city government pointed to the perforation of artesian wells, but this argument did not gain traction among scientists such as Leopoldo Río de la Loza and Ernesto Craveri, who dismissed the "common doubts of those who fear that these waters are not permanent," saying that it would be "very strange" if the main aquifer (the third one down) lacked water, even in the dry season..$^{30}$ When the flow of waters from many artesian wells dwindled in the 1870 and 188 os, the usual diagnosis was not a reduction of water pressure due to overextraction, but rather that the wells were clogged..$^{31}$

Unlike the intensely managed and legislated surface water, it was not at all clear how to manage or resolve conflicts over groundwater. For example, a well was opened in the 1860 s in the public plaza of Atzcapotzalco that served a group of nearby homeowners. ${ }^{32}$ When another well was drilled nearby by another homeowner, this first group lodged a legal case, claiming that the new well reduced the 
flow of water to their previously existing one. Because there were no legal precedents for determining the property status of, and rights to, groundwater, Río de la Loza was asked to comment on the matter. He suggested that the new user should utilize a different aquifer, at a different depth, but was the first to admit this was not a solution that could be made universal.

Instead of confronting conflicts over groundwater by regulating extraction, the city government sought once again to increase supply. Reduced flow from the Chapultepec springs prompted a two-pronged effort. First, the government purchased titles to mercedes to increase the amount of water it owned in the Albercas de Chapultepec. The Alberca Chica was fed by the springs and supplied the Belen Aqueduct. The Alberca Grande, also known as the Alberca Exterior, was a deposit on the southern edge of the Bosque (where Avenida Constituyentes is today) that was used to supply a house, fields, and orchard in Tacubaya owned by José Amor y Escandón, a descendent of the Conde de Miravalle. ${ }^{33}$ The title to this water was purchased by the city, along with titles to the "vertientes del Bosque de Chapultepec," which were waters that flowed from the Chapultepec springs, but which were not captured by the Alberca Chica and the aqueduct and flowed southward out of the Bosque. ${ }^{34}$ There was another reservoir, farther along, belonging to the Hacienda de la Teja. ${ }^{35}$ In addition to these water purchases, the city government cleaned and fixed the Alberca Chica so that it would store more water. As a result of these measures, in 1870 the engineer Manuel Patiño reported that the leaks in the Alberca Chica were all repaired and soon there would be more liquid than could fit in the aqueduct. ${ }^{36}$

This remedy for the shortage of water for the city came at the expense of those who, like the large landowner José Amor y Escandón or the inhabitants of the barrio of San Miguel Chapultepec just south of the Bosque, had used these waters previously. ${ }^{37}$ At the end of the nineteenth century this area lay on the outskirts of the city, and Amor y Escandón owned a swimming pool with dressing rooms that was a popular destination for both city dwellers and foreign travelers such as Gilbert Haven, who described an artesian spring that was "the private property of Señor Escandón, who makes many a penny out of its waters." ${ }^{38}$ In a letter explaining his grievances, Amor y Escandón argued that the city's effort to remedy the water scarcity led it to take "all the measures necessary" to capture the flow from the hardwater springs of the southern part of the Bosque, including building levees and dikes that prevented the water from reaching his alberca, or the lands of the Teja and Condesa haciendas, to whom that water had customarily belonged. Amor y Escandón told the city that the loss of water forced him to close his baños, countering the assumption that the city water supply should be the foremost priority with the argument that the baths were beneficial for public health. ${ }^{39}$ It is ironic that at least some of the water that was taken from the Escandón swimming pool in fact ended up in the city's bathhouses after a long trip through the aqueduct. 
"We pass out of the gate [of Chapultepec Park], ride under the shading willows by the watercourses, enter the gardens of the bath, and the enclosure of the spring. Here is a pool fifty feet square and forty feet deep. The water is so clear that you can see it breaking out of the rock-bed ... amidst the ferns and grasses that cover that natural floor with a perpetual carpet. Here to plunge you will find delightful. ... An adjoining square the water flows into, whose floor is paved with tiles, and whose depth is not above your neck. ... A like bath for ladies is nearby, and a saunter in the garden follows the refreshment."

-Gilbert Haven, 1875

Source: Haven 1875: 224-25.

As wells dried up, even more were perforated. In 1900 the city counted 1,200 artesian wells, and they were common outside of Mexico City as well. Jalisco, San Luis Potosí, Querétaro, and other states had wells for irrigating cities and haciendas by the 1860 os. In Celaya, Guanajuato, artesian wells tapped thermal aquifers to supply bathhouses and water fields. ${ }^{40}$ In 1873 , a traveler to that city described a "bathing establishment, which is supplied by warm water from an Artesian well ... There are a series of private compartments, and a large public basin sufficiently deep for swimming purposes." ${ }^{41}$

The access to groundwater between 1850 and 1900 revolutionized water culture in Mexico, marking the beginning of an age of hydraulic opulence and optimism that continued through much of the twentieth century. Consumers, in particular, quickly grew accustomed to this new supply of water and practices such as frequent bathing by immersion and swimming that the water enabled. Some water managers and scientists also assumed that the centuries-old limits to Mexico City's water supply had been overcome, despite evidence that subsoil water was finite and its extraction caused environmental health hazards and land subsidence. However ephemeral it was, plentiful cheap water restructured feelings about the relationship of people to their waters and set water managers on a path of increasing supply from which they have not since wavered. Aquifer depletion reduced hydrostatic pressure and many artesian wells stopped flowing, but the advent of electrical service at the end of the nineteenth century made it easy to pump the water from those wells. People got used to having copious quantities of fresh potable water at hand, and this assumption of hydraulic opulence drove ever-greater efforts to harness water. To sustain the expansion of water consumption and supply, in 1884 Antonio Peñafiel set his sights on a bigger prize: the springwaters of Xochilmilco, twenty-five kilometers away on the southern edge of the Valley of Mexico. These works were completed in 1908, the first of many such projects that steadily increased the water consumption of Mexico City over the last century. 


\section{THE EXPANSION OF SOCIAL BATHING}

Zopopan, Jalisco, Mexico, 1840. A typical Sunday morning in late spring in western Mexico; the land thirsting for the summer rains soon to come. On the road leading out of Guadalajara to the west carriages of the well-heeled jostle past folks walking in huaraches [sandals], all making their way to the public baths near the towns of Zoquipa and Atemaxac, a mile and half from the city. The small river is low in the dry season, and there are bathhouses installed all along its course: improvised structures made of carrizo reeds with grass walls and roofs that afford some privacy to the modest and the decent. Men and children sit and splash in the water, laughing and playing, some relaxing. Others have retired to the grassy embankments to enjoy picnics and purchase "exquisite watermelons and sweet melons from Caxititlan" from throngs of itinerant vendors announcing their goods in crisp shouts. Some add to the bustle by singing along with the musicians wandering among the crowds. The young women walk in pairs and threes along the riverbank in their weekend attire, freshly picked wildflowers tucked into hair and hatbands. They are waiting for the waters to warm up so they can take a dip in the early afternoon. Local indigenous people organize the whole affair, renting out the bathhouses, selling food, digging out gravel to form swimming pools in the river, and tending the grassy embankment. The dark clouds assembling overhead in the late afternoon signal the end is near for the short summer season of outdoor bathing. When the rains finally come in force, the locals will take down the bathhouses and store the materials, before the rising waters wash the baths into memory. But come next summer, fun and fashion will once again get urbanites from Guadalajara up early in the morning to make the trip to the baths of Zopopan.

-Ignacio Cumplido, 1842

Source: Cumplido 1842: n.p.

How did Mexicans bathe in the nineteenth century? How did bathing practices change after 1850 with the hydraulic opulence created by artesian wells? How was ecology and infrastructure related to culture? Bathing and swimming, like so many quotidian experiences and activities, are often hard to discern in the archival record. Almanacs and travel literature, however, afford ethnographic glimpses of these activities in Mexico in the nineteenth century. At the same time, these are always partial, selective visions that tell us just as much about the cultural assumptions of their narrators.

In 1842 Ignacio Cumplido portrayed the leisurely bathing practices of elite urban Mexicans in a landscape specially managed for this activity. Alexander Forbes, traveling through Tepic in 1849 and 1850, noted a similar arrangement of bathhouses "made of wattles, and thatched ... situated at the river side, where 
the stream is tolerable deep ... divided into different compartments, and much used by the better class of inhabitants." ${ }^{42}$ Bathing among well-to-do Mexicans was commonplace, just as it was for their European counterparts, who during the nineteenth century turned freshwater, mineral water, and seawater spas and resorts into mass leisure destinations. The seaside town of "San Blas," Forbes continued, "is frequented by the Tepiqueños, who during the latter part of the dry season, come down for the sake of sea-bathing." ${ }^{43}$

Poor Mexicans ran the bathhouses for the wealthy, but they too bathed. In 1828 George Lyon visited the Pánuco River near Tampico, and described people "bathing in the river whole families at a time, which appears to be their morning and evening custom." 44 "Such families as choose to," he continued, "devote a little trouble and expense to decency, small spaces are staked off near the banks, and lightly covered with palm branches: but such niceties are not much attended to; both sexes bathe without scruple at the same time, and many of the young women swim extremely well." 45 Steaming up the Río Bravo/Grande in the 1840 , Corydon Donnavan spied "droves of joyous young girls disporting like mermaids among the waters." ${ }^{6}$ A decade later on the same river, Emmanuel Domenech noted that "a number of people of every age and each sex were bathing." ${ }^{47}$ Obviously impressed by the propensity of Mexicans to take to the waters, another traveler in the 1840 s declared, "whenever I was in sight of the river, or the canal of the mills, I could behold men, women and children floundering in the water." ${ }^{8}$

It is clear in these accounts from the mid-nineteenth century that bathing and swimming in springs, rivers, and seas were social activities that were fun for people from all walks of life. In the torrid river drainages of the Gulf Coast bathing and swimming allowed them to cool off and play. But bathing was also about cleaning bodies and clothes. Except for the wealthy, who had servants to do their work, people swam, bathed, and washed clothes at the same time. Alexander Forbes described elite social bathing, but also noted that the humble people in Tepic went to "pozos (swimming holes) ... much used by laundresses and bathers . . . usually large holes dug just below the springs." ${ }^{49}$ On the river in the nearby city of Colima, John Lewis Geiger described the "numerous baths erected along its course, and the temporary laundry establishments," all grouped together. ${ }^{50}$

Women, playing and bathing, attracted the interest of travelers, men especially, who never failed to comment on their nakedness. When George Ruxton rode into Querétaro on horseback in the mid-1840s, he was surprised to come across "a bevy of women and girls 'in the garb of Eve' and in open day, tumbling and splashing in the water." When his group stopped to watch "they were attacked by the swarthy naiads with laughing and splashing, and shouts of 'ay que sin verguenzas!' - what shameful rogues!_;echales muchachas! - at them, girls; splash the rascals-and into our faces came showers of water, until, drenched to the skin, we were glad to beat a retreat." ${ }^{11}$ In Tepic's river Alexander Forbes always found a way to gaze upon "two or three damsels sittin' in it, rather in undress, washing their hair." "The 
women," he continued, "all have beautiful hair, and seem to take great pains in washing and cultivating it, as you may see them all day in the river by scores." ${ }_{52}$ These passages resound with the orientalist titillation of the odalisque, but nevertheless show that undressing and bathing in public was an everyday and rather unexceptional activity. The forms of modesty, honor, and respect that without a doubt regulated this activity were beyond the comprehension of the travelers, who mistook their ignorance of local scruples for an absence of scruples.

At the end of the nineteenth century the influx of capital to Mexico led to the expansion of infrastructure, economic growth, and the accentuation of class dynamics from the industrial era. These changes had important effects on bathing. When Albert Gilliam visited the Aguascalientes hot springs in 1846 they were "not covered by houses, or shelter of any kind, and both rural poor and city dwellers used them in their rustic state, often seeking cures." ${ }_{53}$ By the 188 os, however there were "extensive and commodious bathing houses ... surrounded with flower gardens" for the wealthy in Aguascalientes, but even more so for the new waves of tourists arriving by train from Mexico City and the United States. ${ }^{54}$ While these bathhouses had shared public swimming spaces, their clients washed in individual bathing rooms, where privacy enabled modesty. Those unable to afford such luxuries continued to bathe as always, in the community waters, often in mixed company.

Travelers to Mexico in the late nineteenth century were likely to be adventurous elements of the leisured bourgeoisie from Europe and the United States, riding the new railroads. They were quite aware of the distinctions between wealthy and poor in Mexico, and how these played out in bathing practices. Privacy and nudity were directly connected to social class, and some travelers recognized this. Despite the flood of capital into Mexico during the Porfiriato, and the rapid growth of economy and infrastructure, many Mexicans were so poor that they had only one change of clothes. Blake and Sullivan remarked "nine times out of ten the one suit, noonday and night, forms the entire stock of wearing apparel." ${ }_{55}$ In other words, when women washed clothes, their owners were naked. As Francis Smith put it, there were two classes in the hot springs in Aguascalientes, "those who have something on and those who have nothing." ${ }^{56}$ Cora Crawford, for example, commented that in Aguascalientes there "runs an acequia where all the washer-women of the town gather," and where "the poor congregate because the luxuries of the private bath-houses are beyond their reach." 57

Travelers in the mid-nineteenth century depicted nude bathing in public as somewhat humorous, but by the late nineteenth century they responded to it as a moral or social problem. On the one hand, consider the shock expressed by Crawford upon witnessing an "inhuman scene" in the hot springs town of Aguascalientes, where, "en cueros [naked], and with utter abandon, men, women and children plunge together into the water." ${ }^{8}$ Julia Jackson described the same scene as "startling": hundreds of people "bathing and disporting themselves in the water, with an absence of bathing dresses and an unconsciousness of being visible 
to the naked eye." 59 On the other hand, some travelers adopted a position of cultural relativism and self-reflective detachment. Frank Collins Baker viewed a scene of men and women bathing naked-each group on opposing banks of the riverwith the scientific eye of a naturalist. "It seemed rather strange to us," he reflected, "but was the custom, and of course, aroused no curiosity among the inhabitants." Francis Smith also saw mixed-sex social bathing by the poor as "one of the customs of the country." ${ }^{11}$ Others recognized the practicality of this kind of bathing. "Judging from the number of primitive bathing and washing establishments we met by country brooks and city ditches," Mary Blake and Margaret Sullivan wrote, "wherein father, mother, children and clothes were all being cleaned together, I am inclined to think they prefer the public demonstration. And why should they not, if it be simple and easier?" ${ }^{2}$ Regardless of the stance taken by the traveler, these accounts reflect a widening gap in the bathing infrastructures and practices of the wealthy and poor in many places in Mexico during the second part of the nineteenth century.

The narratives about bathing display the perspective of the narrators, but they also provide ethnographic glimpses of everyday interactions that people had with water. For example, even as they eroticized Mexican women, travelers saw them as workers, washing clothes and raising children. Donnavan argued that "women perform this very necessary part of household labor, in the river," ${ }^{3}$ and Alsden Case described:

scores of women contentedly scrubbing, sudsing, and wringing their clothes, for the river bank is the universal washing place in Mexico. Flat stones served as washboards. All the bushes and rocks of the vicinity were decorated with clothes. And the bathers! Children, children everywhere, with skins all shades of brown. Every woman had brought her tribe, and judging from the appearances, their clothes were being washed "while they waited!"64

The same scene was repeated in the urban bathhouses. Antonio García Cubas revealed his anxieties about class and contagion when he described the "dirty custom" of mothers bathing their children in their leftover bathwater in the small wooden tubs that lined the collective bathing rooms of the downtown bathhouses that served the poor, rooms still known in 1900 as temazcales despite the fact that those steambaths had been mostly eliminated by that time in Mexico City. ${ }^{65}$ The gendered division of labor charged poor women with the responsibility for washing clothes and bathing children-their own as well as those of others.

Travelers understood their social distance from and uneasiness with poor Mexicans in the idiom of cleanliness and hygiene. Blake and Sullivan had been told that Mexicans were dirty, but they discovered that bathing was directly related to the availability of water. "We found them dirty," they wrote, "as regards personal cleanliness, in towns like Chihuahua and Zacatecas, where water has to be dipped with a gourd from the basin of a stone fountain, with scores awaiting their turn, 
or bought from a carrier. But in Aguas Calientes . . . there was no suspicion of uncleanliness." ${ }^{66}$ Sometimes a traveler would go to lengths to reconcile the preconception that Mexicans were dirty with the empirical data that they were constantly bathing. "Though every shop in every city keeps and sells vast quantities of soap," wrote Frederick Ober, "and though everybody in the neighborhood of a stream is constantly washing, both himself and his garments, yet [sic] every person of the lower order is as dirty as though just dipped in a city sewer." ${ }^{67}$ Others racialized the perception of uncleanliness, assuming that all who did not bathe were Indians. "The bulk of the poorer population of the capital are Indians, who greatly resent any sanitary reforms," declared William Carson, "the Indian masses regard water with aversion and soap with horror." ${ }^{38}$ Joséph McCarty extended this derision to poor mestizos, who were, he said, "not over fond of the bath tub." ${ }^{69}$

Durango, 1912. "the mozo [attendant] led us to a large room, with a window opening into a garden, where we could see orange trees and flowers. In the center of the room there was a huge tank, perhaps eight feet square and four feet deep, empty and spotlessly clean, with steps leading down to the bottom. The mozo brought fresh straw mats, two large cotton sheets, rough towels, a little toilet glass with fittings, soap and zacate [fiber], which does service as a sponge. The soap and zacate were in small, tin dishes which float on the water, and are thus near at hand when required. He next pulled out a wooden plug in the side of the tank and a torrent of water gushed in, filling the tank to the height of a man's waist where we could divest ourselves of our clothing. Bob jumped in without ado; but I paused on the top step and dipped in a wary toe to try the water. Finding it only a trifle cooler than body temperature, I too made the plunge and reveled in the soft, greenish clear water, which carries iron and Sulphur. All the cities of Mexico are favored with fine baths, but for delightful water and arrangements I commend 'las Canoas' of Durango."

—Wallace Gillpatrick, 1912

Source: Gillpatrick 1912: 8-9.

Traveler accounts note the existence of baths in Mexico City in the early part of the nineteenth century, but after 1850 artesian wells supplied bathing facilities throughout Mexico.70 "You will find them everywhere in the large cities," wrote one man in 1886, "and their appointments are first class." ${ }^{71}$ Travelers lauded the baths in Veracruz, Orizaba, Xalapa, San Luis Potosí, even the remote northern city of Durango. ${ }^{72}$ And while rural dwellers continued to utilize rivers and springs for washing, bathhouses were also increasingly common even in small towns in Mexico. In 1867, for example, James Elton wrote that "the Mexicans are in advance of many European cities with regard to their baths, for in every small town you will 
find at least one Casa de Baños ... all of them being clean and neatly kept, and the tariff exceedingly low." 73 Twenty years later Fanny Iglehart noted that "comfortable and luxurious public baths-warm and cold-for all classes exist everywhere."74 Guadalajara was said to have twenty-six public baths at the turn of the twentieth century. By that time many Mexicans in towns and provincial cities had grown accustomed to bathing frequently in the profusion of public baths, as very few private houses had bathrooms before 1900.

Mexico City, 1886. “... while the boys went on to the castle, the girls were left at a corner where a long sign on some low rambling building advertised the Baños de Rosario. They passed through a gateway into a little office with a counter, where tickets were given them in exchange for a moderate sum, and then, following a loosely clad muchacho across the usual garden, they were shown into the bath. It was an immense high place, lighted only from the top, and when the high double door was closed upon them, and Bessie had drawn a huge bolt inside to secure it, they felt somewhat solemn, for all was still within except a sound of rushing water, although in the distance they heard splashing and the laughter of other bathers in other rooms like this one. The floor was brick, the whole space being occupied with a round swimming-place twelve of fifteen feet across. Except a walk two or three feet around it. The edge of the bath was higher on one side than the other, so that running water, coming into the bottom of the bath, while it kept it constantly full, was constantly flowing over the lower margin, where it ran off through a sort of trough. In a moderately dry corner, stood a dressing table with a glass over it, covered with the usual bath implements. There were a couple of chairs by it, with matting in front of them for the feet. In the opposite corner was a shower-bath, and in the space between the clear green reservoir of fresh water, about four feet deep, with a smooth bottom of red brick. It was most inviting. Bessie scorning the steps, had soon plunged in, and was swimming about joyfully in the mild soft water. Helena more cautiously descended the steps and found the water just up to her chin. When they were refreshed rubbed and dressed, they came out again into the office. Bessie thought she was to return the torn-off scraps of yellow tickets which the muchacho had given back to her, but a chorus of assistants exclaimed that these were good for a return ride to the city."

-Edward and Susan Hale, 1893

Source: Hale and Hale 1893: 179.

It was Mexico City, however, that was the capital of bathhouses, and by 1867 "their number was legion." 75 The oldest ones were located in the city center, but new ones sprung up in the late nineteenth century on the outskirts of town, especially along the Paseo de la Reforma, which was planned during the French occupation and often described as the Champs-Élysées of Mexico. Sebastián Pane, the 
entrepreneur who pushed forward the groundwater revolution with his drilling rig, was also a leader in the massification of bathing. He opened the famous "Alberca Pane" ("Pane's Pool") in 1864 on a vacant piece of land on the Paseo de la Reforma near the statue of Cristobal Colon, and supplied its multiple pools, showers, and baths with three artesian wells. Other similar establishments followed on its heels, including the Baños Osorio and Baños Blasio right next door, creating a new genre of bathing establishment - the balneario - that had swimming pools and was as much a waterpark as a bathhouse. Such was the abundance of artesian groundwater that one of the balnearios on the Reforma offered baths for horses, and the Alberca Pane had a free tank of constantly flowing water outside the building for use by soldiers and the poor. ${ }^{76}$ The artesian wells gushed continuously, nourishing the baths before spilling into the drains, sewers, and canals that led east to Lake Texcoco. The Albercas Pane and Osorio each had three artesian wells, and the one that served the main swimming pool of the Pane could fill a water carrier's jar ninety times a minute. 77 These new luxury bathhouses sometimes had romantic names, such as "Baños Factor" and "El Harem," and they offered a wide array of aquatic experiences: "lukewarm baths, hydrotherapeutic baths, russian baths, and turco-roman baths; the bathhouses had installations suited for practicing swimming." ${ }^{38}$

Mexico City, 1886. "On another Calzada, not far away from the Alameda, were the Baños del Recreo, and it was well to take this recreation on their way back to the hotel. A friendly woman, mistress of the establishment, sold them tickets at a counter in a little room at the entrance of the baths. Passing through this they came into a little snug garden, and there was a noise of water rushing, and the sounds of merry laughter from the girl's swimming bath. While their baths were being prepared they sat in the corridor looking at the flowers, while Tom stole a 'ladies delight' for his buttonhole. Then each retired to his or her little cell for a refreshing plunge in warm or cold water, after which they were ready for a brisk walk home, or to take the street car at the archway."

—Edward and Susan Hale, 1893

Source: Hale and Hale 1893: 112-13.

As Macías-González (2012) shows us, during the late nineteenth-century administration of President Porfirio Díaz, going to the new bathhouses was an activity laden with meanings of class, status, and civility. The Alberca Pane was a favorite social setting of the elite, most notably President Díaz himself, who at the advice of his physician and friend, Eduardo Liceaga, sought the fortifying and curative effects of taking the waters. "The Alberca Pane," declared a railway promotional 


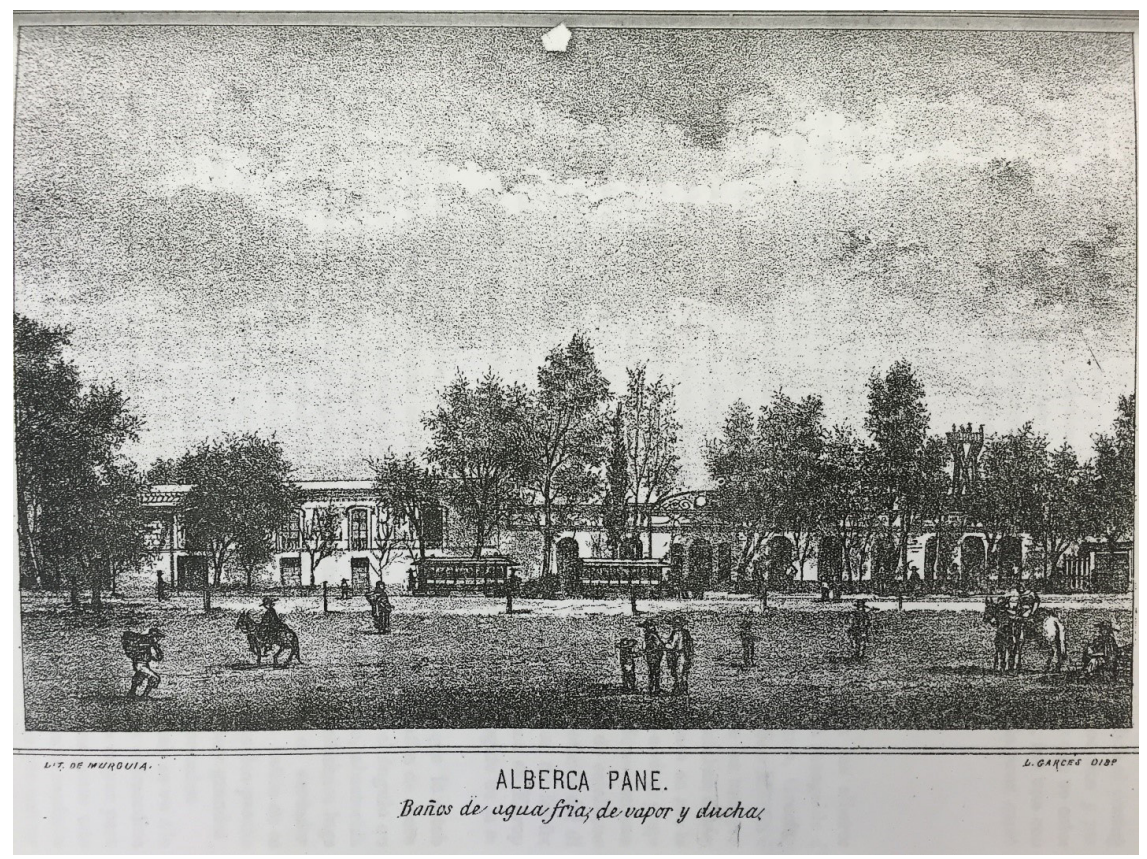

FIgURE 4. Alberca Pane. Rivera Cambas 1880-1883, vol. 2, p. 284.

travel book in 1894, "is the largest and finest in every respect," with "shower, swim, Roman, Russian and Turkish baths." ${ }^{79}$ Much like a European spa, the Alberca Pane offered a wide assortment of cultural and social activities, including gardens, dining rooms, musical performances, swimming lessons, sporting events, hairdressers and barbers, and medical attention. The Alberca Pane's "seductive oriental bath" was especially tailored for the wealthy, with its "beautiful garden and kiosks, carpets, walnut chairs, mirrors, shell-covered furniture" and elaborately tiled pool. ${ }^{80}$ Composer, violinist, and popular icon Juventino Rosas gained much of his fame playing Straussian waltzes for the wealthy at the Alberca Pane and the Baños Factor. ${ }^{81}$ His song "Junto al Manantial" ["Beside the Spring"] was composed for the birthday party of the wife of the owner of one of the baths. ${ }^{82}$ Long weekday afternoons and entire weekend days were spent bathing, eating, socializing, and performing other rituals of class distinction.

As the century progressed, these prominent bathhouses brought together increasingly wider swaths of Mexican society into a hierarchical but still unified space. "There are baths of true luxury," wrote Manuel Rivera Cambas, "and others for social classes with few resources; they are divided in categories aligned with the people that use them, and thus their cost." ${ }^{33}$ And the baths were not just for men, although the rules of propriety ensured that men and women occupied entirely 


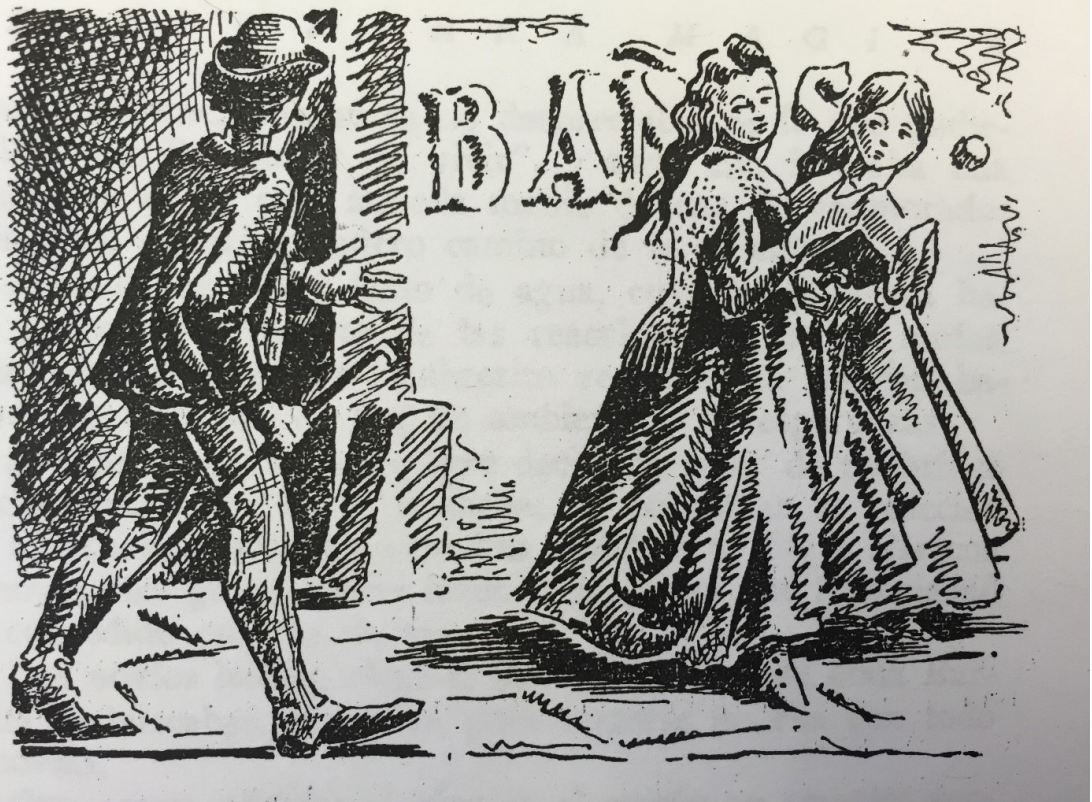

FigURE 5. Baños. De Cuéllar 1889.

separate bathing facilities. In his 1889 novel Baile y Cochino, José de Cuéllar tells the story of three sisters from more humble origins who bathed regularly at the Alberca Pane for hygiene, health, and, not least, to mingle with the well-to-do in these new spaces of leisure. Middle-class Mexicans often took the "baths route" (circuito de baños) streetcar, operated by the Alberca Pane, paying 50 centavos for a ticket that included entrance to the Russian baths, 25 centavos for the hydrotherapy baths and lukewarm baths, or 12 centavos for the coldwater baths. ${ }^{84}$ It was ordinary to see parades of young women with their hair in towels, returning home after their baths on the "Baños" streetcar line. ${ }^{85}$

Poor city dwellers also participated in the public rituals of hygiene and cleanliness. Luxury bathhouses such as the Alberca Pane brought together the middle and upper classes in shared spaces and activities that fortified a notion of belonging to a civilized nation, but they also provided baths for the poor. While the poor could not afford to use the facilities within the bathhouses, they made use of a tank offered by the Alberca Pane free to the public on the street, and in this way experienced the hydraulic opulence and public rituals of hygiene and cleanliness. ${ }^{86}$ When the flow of its artesian wells diminished in the 189os, the Alberca Pane asked for three mercedes of additional surface water from the city government to support an expansion of its facilities and "a reduced price to poor people," 
which was awarded on the basis that the bathhouse provided a "benefit to public hygiene and health." ${ }^{\text {87 }}$

In the cities of Europe and North America, municipal governments built bathhouses beginning in the last decades of the twentieth century with the purpose of promoting cleanliness among the working class, ${ }^{88}$ and the government of Mexico City made similar plans, beginning in 1881 , to provide public bathhouses in each of the neediest zones of the four cardinal directions in the city, where, city regidor (alderman) Ignacio Toro declared, "the poor bathe and wash their clothes in the canals and ditches, which is manifestly unhygienic" and encourages "immoral" public nudity. ${ }^{89}$ The public works commission explained to the regidores that public bathhouses had "been built with brilliant success in England; and in France a fund of 600,000 francs had been created for the same purpose." 90

"Thanks to notions of popular hygiene that spread more and more every day;
thanks to the progress and aspiration of our civilization; we vehemently support,
in order to secure greater well-being, the widespread use of baths in our city.
You can see a great number of people of the lowest classes that make use of the
canals and even drainage ditches to wash their clothes and bodies, mostly on
their days off. If they do it in those places that are full of germs of diseases that
spread through the waters, it is because they have nowhere else to do so for free."
-Mexico City Public Works Commission, 1895

Source: AHCM, Policía en General, Vol. 3639, Exp. 1064 (1895).

These planned municipal bathhouses were to provide immersion baths as well as laundry facilities, and in 1887 eleven thousand pesos were authorized for the construction of the first such facility in Mexico, dedicated to serving women. The money never appeared, however, and the project ran afoul due to a number of other problems. The bathhouses required a quarter of a city block, and such properties were unavailable, as was the water needed for the bathhouses. In 1891 a new proposal was submitted to the city council by Antonio Torres for a smaller, less costly bathhouse, with multiple entrances, fewer laundry basins, and more bathtubs. Torres was particularly worried about offering too many sinks, because "it would enable the paid washerwomen to go there rather than those truly in need." ${ }^{\text {91 }}$ By June of 1891 the city had agreed to purchase a lot in the Colonia Morelos for the bathhouse, and contracted Guillermo Paterson to drill an artesian well to supply the water.

In the end, however, the bathhouse was not built. Paterson assured the city that water had been found in a nearby lot at 100 meters, but only found the liquid at 222 meters after drilling for seven months, more than doubling the costs. The process of purchasing the lot for the bathhouse dragged on and on, and the money for the 
construction was never delivered. The burbling artesian well became a fountain for the neighborhood, and someone installed themselves as caretaker of the well and the property..$^{92}$

"In April to June, when the heat is greatest in the capital, you see the masses of inhabitants going to the pools with the most extraordinary dedication. But not only at that time: they go most of the year, because in addition to the pools fed by artesian wells there are also showers, russian [sic] baths and all the others that are used for medicine or recreation. In June more than 40,00o bathers go to the pools, arriving on the trams, in cars, on foot or horseback, happy caravans going to those wonderful leafy spaces where the trees, the landscape and the company call their attention. There are beautiful young women with their hair down and adorned with flowers, the throngs of vendors selling snacks, and often enthusiastic musicians. .." -Manuel Rivera Cambas, c. 1880

Source: Rivera Cambas 188o-1883, vol. 2: 285 .

The Feast Day of Saint John the Baptist, June 24, was a crucial event in the conformation of water culture in modern Mexico City. On this warm summer day Mexicans traditionally celebrated the Catholic association between purification and water by visiting a bathhouse or a nearby river or spring. A common saying was that bathing on that day would give "beauty to the maiden, vigor to the matron, and freshness to the old maid."93 This custom grew more elaborate with the hydraulic opulence of artesian wells and the proliferation of bathhouses such as the Alberca Pane in the late nineteenth century. The baths and pools filled to capacity on that day with children and adults enjoying the water much more in pursuit of ludic than spiritual ends.

"From the first ring of the church bells in the morning [of Día de San Juan], those who were heading to the baths took to the streets happily singing. ... Some took the road to Chapultepec in wagons and trams, others headed off to the different baths around the city, which were swept, washed and decorated with willow branches around the patios, doors and windows, and sparkling everywhere with decorations.... The energy in the baths were extraordinary, and the general happiness was increased by the sounds of the musicians. The bathers reflected this emotion with their shouts and laughter, the splashes made every time one of them dove in. ... It was a custom in all the baths to give away fruit, soap and sponges. . ."

Source: García Cubas 1904: 374. 
The dia de San Juan, like other festival days, was intensely social. Bathhouse owners adorned their buildings with plants, banners, flags, and other decorations, and vendors set up carts and stands catering to the crowds that descended on the baths. Grooming items were available everywhere, and the bathhouses themselves offered gifts of soap and small scrubbing pads made of cactus fiber (estropajos, made of ixtle) to their clients. In addition, all sorts of food was available on the streets outside the bathhouses and pools.

"In one tank one hundred and fifty or more bathers may be seen at once, throwing themselves head first, diving and swimming, or standing half submerged, or perhaps jumping from the spring-board. To all these gyrations add the screams of the multitude, the shrieks of the bathers and the people on shoe selling a thousand and one articles beneath the rays of a scorching sun, to complete the scene. Though many pursuits and avocations are carried on, the dominating and supreme desire of the crowd is to get wet."

-Fanny Iglehart, 1887

Source: Iglehart 1887: 275 .

Bathing in the bathhouses of late nineteenth-century Mexico was an activity in which a wide swath of society participated, and it helped generate a sense of the nation rooted in traditional customs such as those of the dia de San Juan as well as new practices of civilized cosmopolitanism. Artesian wells allowed sumptuous practices of immersion, once a symbol of European culture and a privilege of the elite, to soak far down into Mexican society. Bathing establishments remained segregated along class lines, but the availability of bathhouses at all price points made it possible to imagine that all Mexicans were unified as a nation that bathed together. This vision placed Mexico on the same level as Europe, and was bolstered by an evolutionary narrative that seized upon bathing and cleanliness as signs of civilization. As one intellectual from the time stated, "baths with the luxury and dimensions that the ones on Bucareli and Reforma already have in Mexico, are an undeniable proof of advanced civilization."94

While in the 1840s Ignacio Cumplido described the rustic baths of Guadalajara as desirable for their simplicity, and derided the Roman baths as decadent, by the 188os Rivera Cambas cast this classical opulence in a positive light, stressing the continuities with modern Mexico. "Although our civilization has not refined its sense of taste to the degree that it was in the era of Cicero, we nevertheless have beautiful medicinal and recreational baths," he wrote.95 "Someone once said, and was right," declared Prantl and Groso, "that the level of culture of a people is manifested in the number and quality of its bathhouses." Mexico was still at a middling level in these 
terms, they continued, but nonetheless "fulfilled the requirements of cleanliness, comfort and hygiene demanded by such a civilized metropolis as ours." ${ }^{96}$

Baths and bathing in Porfirian Mexico evoked classical civilizations by borrowing Roman, Greek, Moorish, and Aztec elements. As Mexico's economy and state grew in the last decades of the nineteenth century, the emergent Mexican bourgeoisie pushed back against unilineal evolutionary thinking that cast the country as barbaric and "backward," by claiming its own classical tradition. Just as European countries took the mantle of civilization from Greece and Rome, Mexican intellectuals such as Antonio Peñafiel made an antiquarian effort to recover Mexico's roots in the complex societies of Mesoamerica. ${ }^{97}$ National histories from this time drew continuities to the grandeur of Tenochtitlán as well as Spain, ${ }^{98}$ a narrative that was projected internationally in settings such as the Universal Expositions in Paris in 1889 and 1900, for which Peñafiel designed a "Mexican Pavilion" in neoAztec architectural style. ${ }^{99}$ At home in Mexico City, statues of Cuauhtémoc, the last Aztec emperor, and two "Indios Verdes" graced the Paseo de la Reforma along with those of Christopher Columbus and King Carlos IV of Spain.

"Who says our beloved Mexico is not civilized? What a crass mistake! And is there anyone in Mexico who complains of an incurable disease? No one, no one, no one. Who is going to get sick in Paradise? Mexico is the Garden of Eden with those baths."

—Artemio de Valle Arizpe, 1946

Source: De Valle Arizpe 1946: 156.

Mexico's bathhouses evoked the splendor, opulence, and refinement of the classical Mediterranean world. The "Coliseo Nuevo" (New Coliseum), founded around 1850 by an expatriate Italian general, was renamed "The Harem" soon after. ${ }^{100}$ In 1887 the Alberca Pane installed a "Turkish-Roman" bath they called El Hammam (the Arabic name for the classical Islamic bathhouse) that offered a sumptuous Roman sequence of water encounters: the tepidarium, the caldarium, the laconicum, the alipterium, the lavatorium, and finally "showers of different temperatures" or a cold plunge bath. ${ }^{101}$ The "Turkish bath," introduced around 1900 to Mexico City, offered a hot steam treatment quite similar to that of the temazcal before it, but for an elite clientele and with very different connotations. ${ }^{102}$

Mexico's civilized trajectory could also be clearly seen in the Bosque de Chapultepec. The Bosque was widely known to be a hunting ground and park for the Aztec rulers, and the famed springs, the pools that collected their water, and the aqueduct that delivered it to the city center were all associated with the Aztecs, who first built the water system. The smallest spring-fed pool was the source of 


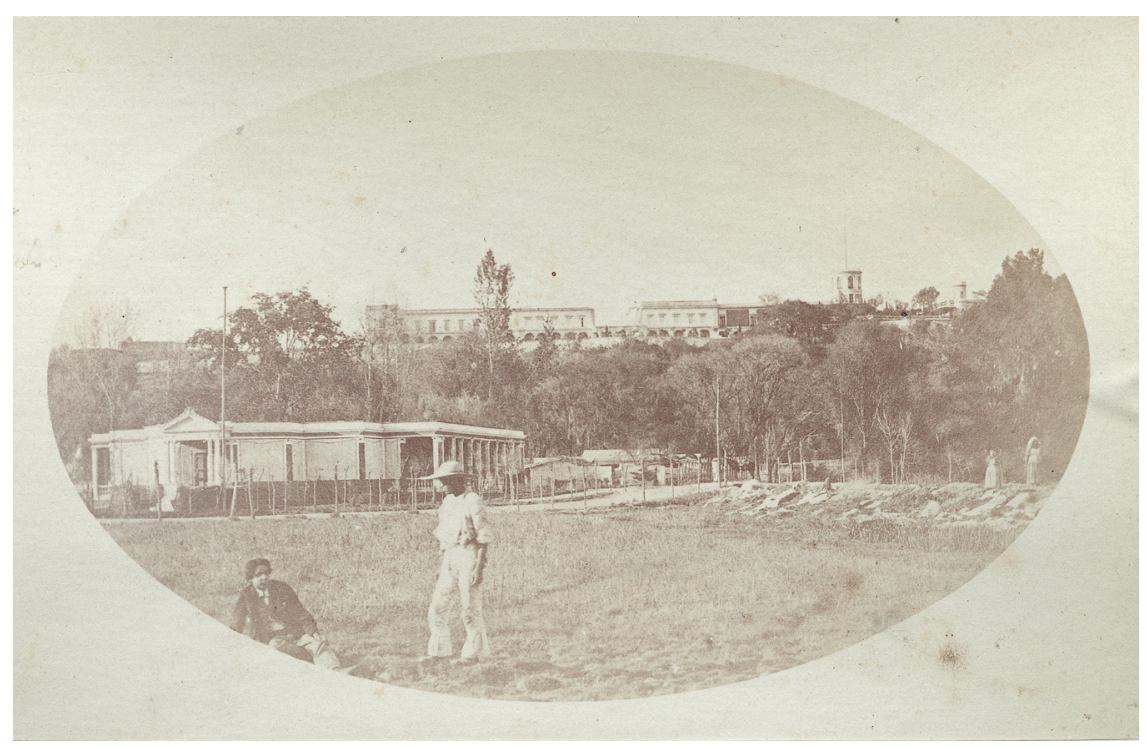

FIGURE 6. Baños de Chapultepec. Michaud 1874. With permission of Universidad Nacional Autónoma de México, Instituto de Investigaciones Estéticas, Archivo Fotográfico Manuel Toussaint, Colección Julio Michaud.

water for the aqueduct, and was the oldest. Travelers and locals viewed it as "an interesting relic of Moctezuma's glory," referring to it as "Moctezuma's Bath" and "Moctezuma's Pool," and believing that it "was probably used by him." ${ }^{103}$ In fact, the pool was built as a reservoir for the water that flowed to the aqueduct, and it is highly unlikely that it was used by Moctezuma for bathing or swimming given that it was the water source for the city, and that people "bathed" in temazcales. The idea that this was an Aztec bath may have been influenced by a famous pool in the hills near Texcoco, known as Nezahualcóyotl's Baths, a common stop on the itineraries of travelers to Mexico since the colonial period that gained renewed fame with the growth of tourism in the late nineteenth century.

By the 1860 s the owners of Chapultepec's Alberca Grande (also known as the "Alberca de los Nadadores" or the "Swimming Pool") had built a bathhouse to serve the public. ${ }^{104}$ This was the most popular swimming pool for city dwellers of some means until the Alberca Pane and its neighbors opened up on Reforma. The bathhouse was built in a neoclassical architecture, and decorated "in the style of Pompeii," with a large swimming pool fed by the springs and smaller, private pools and rooms that received the water from the Alberca Grande. ${ }^{105}$ There were gardens with sandy walkways shaded by enormous ahuehuete (cypress) trees. Antonio García Cubas describes (with his typical thesaurical largesse) a "rich and endless spring almost overflowing the pool that bounded its transparent waters, where the 
good swimmers showed off their prowess, jumping off the high guardrails into the liquid to catch a silver coin as it sank, or to lie beneath the tree roots in the water to display their ability to hold their breath as well as the best divers." ${ }^{106}$ One traveler called a swimmer "a swarthy son of Aztecs", reinforcing the popular narrative about the classical Mesoamerican origins to bathing in Mexico. ${ }^{107}$

The Alberca de los Nadadores operated from the 1860 s until about 188o, when the profusion of artesian wells around the springs reduced their water levels so much that the city stepped in to purchase the title to all the springwaters and channel them to the aqueduct that led downtown. So much water was extracted from the subsoil in Chapultepec that the ancient ahuehuete trees-also associated with the Aztecs-began to die, prompting caretakers to ask the city for a concession of springwater to irrigate them. ${ }^{108}$ By the time García Cubas wrote his memoirs in 1904, the pool was dry and already eulogized as the remnant of a noble and hygienic indigenous civilization. "Montezuma's bath still stands," wrote Crawford in 1899 , "a charming bit of ruins." 109

At first only the relatively wealthy could afford the sumptuous, novel encounters with water offered at the city's new bathhouses. But as we will see in the next chapter, as water became more available greater numbers of bathhouses opened, and poorer people had more access to swimming pools, placeres, and showers. Like many other elite practices and symbols, the new forms of bathing were slowly adopted by the masses. By the 1920s Mexico's bathhouses served a mostly popular clientele, as the opulence of water, confirmed by the Xochimilco aqueduct, trickled down through society. Partially as a result of the massification of social bathing, the correct way to wash the body was recast by sanitarians from the public bath to the private domestic shower, which was in turn promoted by the federal government.

\section{CONCLUSIONS}

In 1850 bathhouses and open-air bathing sites were well attended throughout Mexico, and swimming was a popular pastime for many Mexicans. After that, however, new sources of groundwater facilitated a grand expansion of these activities. In Mexico City, swimming pools and bathhouses opened in new neighborhoods along the Paseo de la Reforma, where bathing took on a modern, cosmopolitan air. Chapultepec Park itself had a swimming pool and bathhouse. Social bathing for fun and fitness grew in popularity and many new businesses were opened that offered new watery experiences: saunas and steambaths, hot springs and swimming pools.

This was a significant shift in the encounter that people had with waters: from steaming and washing to soaking and showering. There was a cultural resignification of cleanliness, which was increasingly defined in terms of hygiene and linked to concepts of civilization and progress. The temazcal was cast aside as a tradition practiced by poor and indigenous people, and new bathing practices 


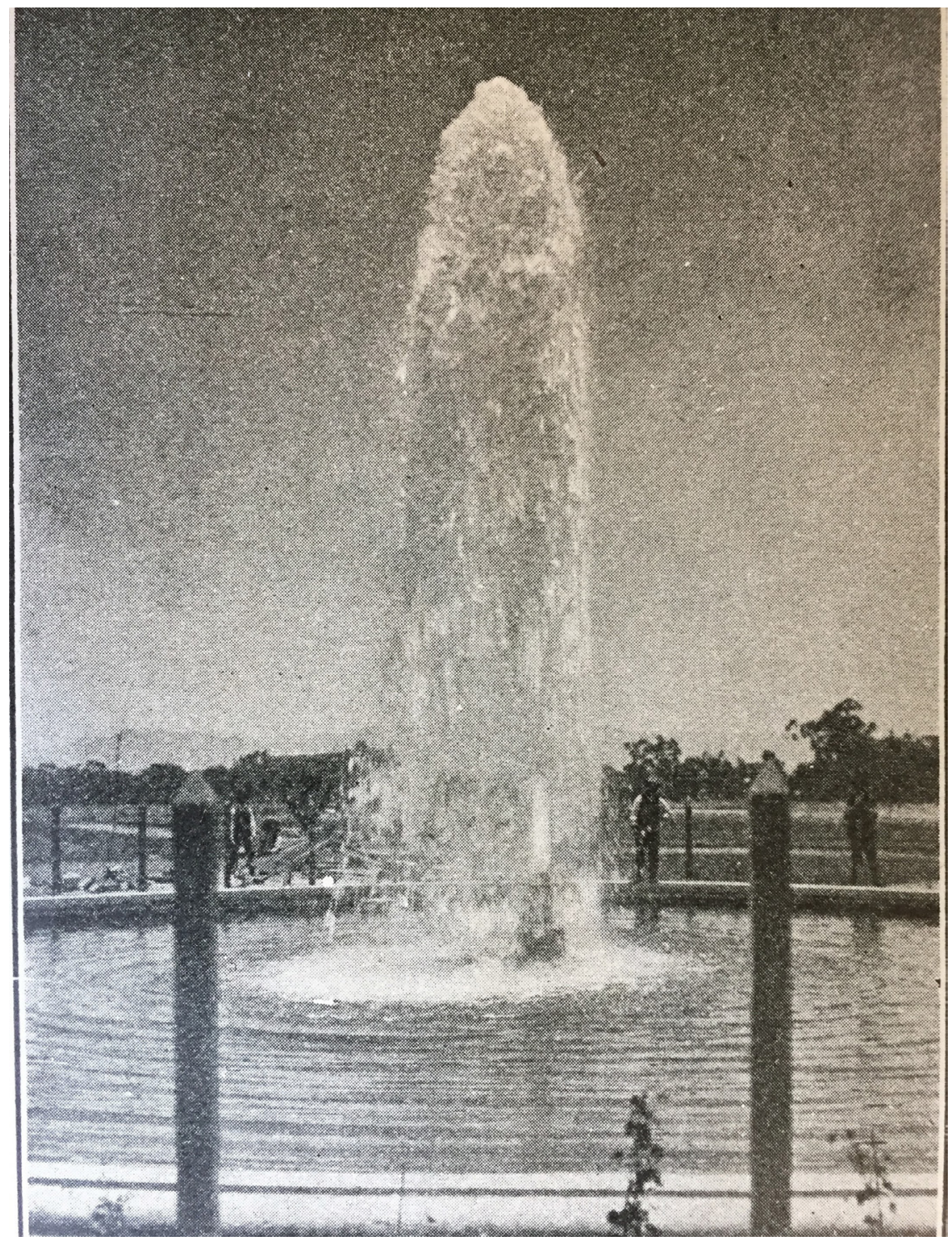

Figure 7. El Pozo "Pimentel," La "Colonia de la Condesa." El Mundo Ilustrado 2, no. 12 (1906). With permission of the Hemeroteca Nacional de México, Fondo Reservado.

of immersion - and even more so, showering-came to be seen as modern and desirable. Sidney Mintz calls this "extensification," a cultural process in which the poor emulate the practices of the wealthy. ${ }^{110}$ But just when the humble residents of the capital gained access to bathhouses, the rich built private bathrooms in 
their homes, which became commonplace in the bourgeois colonias such as the Roma and the Condesa that expanded on the western side of the city. This shift was enabled by groundwater: the Condesa neighborhood was supplied only by artesian wells when building began around $1905 .{ }^{111}$

During the twentieth century, the expansion of urban water systems increasingly provided water to household bathrooms as well as collective bathhouses. Newly built hydraulic infrastructure was considered evidence of both Mexico's status as a civilized nation and the power and authority of the Mexican state. ${ }^{112}$ After the Xochimilco aqueduct was completed around 1910, houses in the new neighborhoods in the wealthy areas of Mexico City were connected to the city water grid and plumbed for showers, a trend that would continue through the twentieth century. Groundwater is of course not limitless, and the boom of artesian wells was relatively brief -1850 to 1900 , more or less. Nevertheless, the groundwater boom produced habits of water use that, even after the aquifers were depleted and the artesian wells trickled out, lived on to motivate the ceaseless twentieth-century drive to build evermore-encompassing works to supply universal, frequent, individualized household baths with uniform, public water. 